\title{
PARLIAMENTARY SPEAKERSHIP: FROM INDIVIDUAL SPEAKERSHIP TO THE COLLECTIVE DIRECTION OF PARLIAMENTARY WORK ${ }^{1}$
}

\author{
Mikel Urquijo Goitia ${ }^{2}$ \\ University of of the Basque Country \\ Correspondence: \\ mikel.urquijo@ehu.eus
}

Received:

19.02.2020

Accepted:

20.05.2020

\footnotetext{
${ }^{1}$ This work was supported by Ministry of Science, Innovation and Universities (Spanish Government) under Grant PGC2018095712-B-100.

${ }^{2}$ Professor of Contemporary History and Member of the Research Group Biography \& Parliament (www.prosoparlam.org).
}

\section{How to cite this paper}

Urquijo Goitia, M. (2020) Parliamentary speakership: from individual speakership to the collective direction of parliamentary work. Spanish Journal of Legislative Studies. (2), p.1-17 DOI: https://doi. org/10.21134/sjls.vi2.1286 


\title{
SUMMARY
}

I. INTRODUCTION. II. THE ORIGIN OF THE SPEAKERSHIP. III. THE TRANSITION TO COLLECTIVE DIRECTION. 1. The parliamentary bureau. 2. The conference of presidents. 3. The reasons for this transformation. IV. CONCLUSIONS

\begin{abstract}
The article explains the evolution of the parliamentary speakership in different countries of continental Europe in the XIX and XX centuries. The text focuses on three questions in order to define how the speakership was shaped in the parliaments that emerged from the liberal revolution: the procedure by which the speaker was elected, the duration of his mandate and his functions. Starting from the definition of the initial model, it analyzes how after the II World War the direction of parliamentary work evolved towards a shared model involving three bodies. These were the speakership itself, the bureau of the chamber and the conference of presidents of the parliamentary groups, with functions delimited among the three bodies and the speakership maintaining those competencies that had necessarily to be performed by a unipersonal body.
\end{abstract}

\section{KEYWORDS}

Parliament, Presidency, Bureau, Conference of presidents, Europe 


\section{INTRODUCTION}

This Art. analyzes the functions of the parliamentary speakership in four European countries (France, Italy, Portugal and Spain). Its specific aim is to explain why over the course of the XIX and $X X$ centuries the individual body for directing the chamber, the speaker, ceded a relevant part of his competencies to the collective body for directing the chamber, the bureau, and the body representing the parliamentary groups, the conference of representatives of the parliamentary groups. This question is analyzed in today's parliamentary systems by Georges Bergougnous 3 , but he does not go deeply into the origin of this change, which is particularly notable in the countries we are studying and has been consolidated in the current period $^{4}$. In our work it becomes clear that in spite of the differences in the parliamentary rules of France, Italy, Portugal and Spain, certain common characteristics and a similar evolution can be detected. This allows us to speak of a model of evolution from individual parliamentary speakership to the collective direction of parliamentary work.

To develop this work we have used primary sources obtained on the websites of the different parliaments ${ }^{5}$ and in the Archivio di Diritto e Storia Constituzionali of the University of Turin ${ }^{6}$. On these websites we consulted the constitutions ${ }^{7}$ and the parliamentary rules ${ }^{8}$ of the XIX and XX

${ }^{3}$ BERGOUGNOUS, Georges. Presiding Officers of National Parliamentary Assemblies. A World Comparative Study. Geneva: IPU, 1997, pp. 91-96

${ }^{4}$ MANCISIDOR, Eduardo. "Funciones y potestades de la presidencia parlamentaria". In Alberto FIGUEROA and Juan Carlos DA SILVA (eds.). Parlamento y Derecho. Vitoria-Gasteiz: Parlamento Vasco-Eusko Legebiltzarra, 1991, p. 159.

${ }^{5}$ Italy: storia.camera.it. France: http://www2.assemblee-nationale.fr/decouvrir-l-assemblee/histoire. Portugal: https://www.parlamento.pt/. Spain: www.congreso.es.

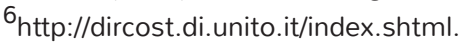

${ }^{7}$ For the French case we consulted: Constitution de 1791 (CF1791), Constitution de 1793 (CF1793), Constitution de 1795 (CF1795), Constitution de 1799 (CF1799), Charte constitutionnelle, 1814 (CF1814), Charte constitutionnelle, 1830 (CF1830), Charte constitutionnelle, 1848 (CF1848), Constitution de 1852 (CF1852), Lois Constitutionnelles de 1875. Loi du 25 février 1875 relative à I'organisation des pouvoirs publics (CF1875-1), Lois Constitutionnelles de 1875. Loi du 25 février 1875 relative à I'organisation du Sénat (CF1875-2), Lois Constitutionnelles de 1875. Loi du 16 juillet 1875 sur les rapports des pouvoirs publics (CF1875-3), and Constitution de 1946 (CF1946). For the Italian case: Statuto Albertino, 1848 (CI1848) and Costituzione della Repubblica Italiana, 1947 (CI1947). For the Portuguese case: Constituiçâo portuguesa, 1822 (CP1822), Carta constitucional para o Reino de Portugal, Algarves e sus domínios, 1826 (CP1826), Constituiçâo portuguesa, 1838 (CP1838), Constituiçâo da República portuguesa, 1911 (CP1911) and Constituiçâo da República portuguesa, 1976 (CP1976). For the Spanish case: Constitución política de la Monarquía española, 1812 (CE1812), Estatuto Real, 1834, (CE1834), Constitución de la Monarquía española, 1837 (CE1837), Constitución de la Monarquía española, 1845 (CE1845), Constitución de la Monarquía española, 1869 (CE1869), Constitución de la Monarquía española, 1876 (CE1876), Constitución de la República española, 1931 (CE1931) and Constitución española, 1978 (CE1978). The abbreviated names of the constitutions are given in brackets. These abbreviated names will be used throughout the article.

${ }^{8}$ For the French case: Règlement a la usage de l'Assemblée Nationale, 1789 (RPF1789), Règlement de I'Assemblée Nationale Législatif, 1791 (RPR1791), Règlement de la Convention Nationale Législatif,1792 (RPF1792), Règlement du Corps Législatif, 1800 (RPR1800), Règlement de la Chambre des Députés des Départements, 1814 (RPF1814), Règlement de la Chambre des Députés des Départements, 1830 (RPF1830), Règlement de I'Assemblée Nationale, 1848 (RPF1848), Règlement du Corps Législatif, 1861 (RPR1861), Règlement de la Chambre des Députés, 1876 (RPF1876), Règlement de la Chambre des Députés, 1915 (RPF1915), Règlement de l'Assemblée Nationale Constituante, 1945 (RPF1945), Règlement et résolutions réglementaires de l'Assemblée Nationale, 1946 (RPF1946), Règlement de I'Assemblée Nationale, 1947 (RPF1947). For the Italian case: Regolamento della Camera dei Deputati, 1848 (RPI1848), Regolamento modificato della Camera dei Deputati, 1863 (RPI1863), Regolamento della Camera dei Deputati, 1868 (RPI1868), Regolamento della Camera dei Deputati, 1888 (RPI1888), Regolamento della Camera dei Deputati, 1900 (RPI1900), Regolamento della Camera dei Deputati, 1922 (RPI1922), Regolamento della Camera dei Deputati, 1925 (RPI1925), Regolamento della Camera dei Deputati, 1930 (RPI1930), Regolamento della Consulta Nazionale, 1946 (RCI1946), Regolamento dell'Assemblea Costituente, 1946 (RPI1946), Regolamento della Camera dei Deputati, 1949 
centuries, which enabled us to determine the norms regulating the activity of these chambers. We also took as a referent the most relevant bibliography on the parliamentary speakership ${ }^{9}$ with respect to these four countries. We can say that the bibliography on this topic basically consists in the analysis of the model for each country. There are not many works that attempt to make a comparative analysis with the exception of the cited work by Bergougnous or those by Philip Laundy on the parliaments that took Westminster as their model ${ }^{10}$. But we find that the greatest attention has been dedicated to the British case, or in other countries to analyzing the present shape of their parliaments, while comparisons are not frequent.

On the one hand, our contribution consists in providing an analysis of four countries that, with the exception of the French case, have received little attention in comparative studies; and, on the other, in carrying out a long-term analysis within which the change in the direction of parliamentary work that occurred after the II World War becomes more understandable. We consider that in these four countries there is a similar evolution in which the model developed by France has considerable weight.

The origin of the speakership of the representative assemblies is closely linked to the creation of the assemblies themselves. At these meetings it proved necessary to have someone who would direct the sessions, give the floor to different parliamentarians, guarantee that debate procee-

(RPI1949). For the Portuguese case: Regimento para o governo interior das Cortes Geraes, e extraordinarias constituintes, 1820 (RPP1820), Regimento interno da Camara dos Senhores Deputados, 1827 (RPP1827), Regimento da Assembleia Constituinte, 1975 (RPP1975), Regimento da Assembleia da República, 1976 (RPP1976). For the Spanish case: Reglamento para el gobierno interior de las Cortes, 1810 (RPE1810), Reglamento para el gobierno interior de las Cortes, 1813 (RPE1813), Reglamento del gobierno interior de las Cortes y su edificio, 1821 (RPE1821), Reglamento para el régimen y gobierno del Estamento de Procuradores a Cortes, 1834 (RPE1834), Reglamento del Congreso de los Diputados, 1838 (RPE1838), Reglamento interior del Congreso de los Diputados, 1847 (RPE1847), Reglamento interior del Congreso de los Diputados, 1867 (RPE1867), Reglamento para el gobierno interior de las Cortes Constituyentes, 1873 (RPE1873), Reglamento del Congreso de los Diputados, 1918 (RPE1918), Reglamento provisional de las Cortes Constituyentes, 1931 (RPE1931), Reglamento del Congreso de los Diputados, 1934 (RPE1934), Reglamento provisional del Congreso de los Diputados, 1977 (RPE1977) and Reglamento del Congreso de los Diputados, 1982 (RPE1982). The abbreviated names of the rules are given in brackets. These abbreviated names will be used throughout the article.

${ }^{9}$ AGUILÓ, Lluís. "Status y atribuciones de las presidencias de los parlamentos". Anuario Jurídico de La Rioja. 1996. n 2, pp. 467486, AJA, Eliseo. "El parlamentarismo en la democracia (1979-1994)". Hispania. 1995. n 189, pp. 125-148, BALDINI, Emilia. "I Presidenti delle Assemblee parlamentari con particolare riguardo all'ordinamento italiano". Sociologia. Bollettino dell'Istituto Luigi Sturzo. 1960. Vol. 1, n 4, pp. 99-130, DAUDET, Yves. La Présidence des Assemblées parlementaires françaises. Paris: PUF, 1965, DEODATO, Giovanni. “L'Ufficio di Presidenza della Camera dei Deputati”. Rassegna parlamentare. 2002. Vol. 44, n 1, pp. 291-297, FERRARA, Gianni. Il Presidente di Assemblea parlamentare. Milano: Giuffrè, 1965, FURLANI, Silvio, et alii. I Presidenti della Camera. Roma: Editalia, 1988, GARRIGUES, Jean (ed.). Les Présidents de l'Assemblée nationale de 1789 à nos jours. Paris: Classiques Garnier, 2015, JERÓNIMO, Estefanía. La Presidencia del Congreso de los Diputados en el sistema constitucional español de 1978. Málaga: Ayuntamiento, 2006, JERÓNIMO, Estefanía and MORALES, Miguel A. La presidencia de las Cortes en el constitucionalismo histórico español. Almería: Universidad, 2004, MANCISIDOR, Eduardo. “Funciones y potestades de la presidencia parlamentaria", pp. 155-233, OLLER, Maria D. “Los órganos de dirección de las Cámaras: Presidente, Mesa y Junta de Portavoces". Revista de la Facultad de Derecho de la Universidad Complutense de Madrid. 1986. n 10, pp. 87-109, SÉGUIN, Pierre. 240 dans un fauteuil. La saga des présidents de l’Assemblée. Paris: Éditions du Seuil, 1995, TORRES, Ignacio. Los órganos de gobierno de las Cámaras Legislativas. Presidente, Mesa y Junta de portavoces en el Derecho parlamentario español. Madrid: Congreso de los Diputados, 1987, TRAVERSA, Silvio. “II Presidente della Camera dei Deputati”. In TRAVERSA, Silvio (ed). Il Parlamento nella Costituzione e nella prassi (studi). Milano: Giuffrè,1989, pp. 425-433.

${ }^{10}$ LAUNDY, Philip. The Office of Speaker. London: Cassell \& Co. Ltd, 1964 and LAUNDY, Philip. Parliaments in the modern world. Aldershot: Dartmouth Publishing Company, 1989. 
ded in orderly fashion and ensure respect for the right of all members of the chamber to intervene11. The duration of the speaker's mandate was conditioned by the permanence of the assembly and to the extent that assemblies advanced from meeting occasionally to doing so periodically, the length of the mandate was also altered over time. In the period prior to the liberal revolutions the speaker was appointed by the Monarch, who convened the assembly; or if the speaker was elected by the assembly, he at least had to receive royal approval.

With the liberal revolutions the representative assemblies in continental Europe were transformed into parliaments that changed radically with respect to the previous model. Their members were elected in a different way, directly by the citizens with the right to vote rather than by corporations of different types or because of their status as nobles or churchmen. Their composition changed, in spite of the persistence of elements of the Ancien Régime, whose presence was more important in the upper chambers, and with time the deputies came to be people from varied social backgrounds and not solely representatives of the most privileged groups. The periodicity of their meetings was established in new constitutions and did not depend on the will of the Monarch. The new parliaments were to have certain fixed periods of sessions, and their functions and role facing the monarchy were set out in constitutional texts. In sum, there was a move from the representative assemblies of the Ancien Régime to liberal parliaments. In the words of A. Marongiu, there was a shift from a deliberative assembly to a representative assembly 12 .

\section{THE ORIGIN OF THE SPEAKERSHIP}

Turning now to the countries that concern us, in France (1789), Spain (1810) and Portugal (1820) the existing monarchies gave way before the liberal revolution. In this new framework the speakership was to see changes in its electoral procedure, the duration of its mandate and its functions with respect to the representative assemblies that had met under the Ancien Régime.

The new liberal parliaments created in these years elected a speaker from amongst their members. The idea that all the deputies were equal, with no differences amongst them, was no obstacle to the parliament considering it necessary to elect a person to direct and moderate debates. What emerged was a model of speakership - the speaker considered as a "debating technician"13 - with limitations placed on his powers, as well as on his tenure of the post ${ }^{14}$, influenced by the theories of Emmanuel J. Sieyès ${ }^{15}$. First in France, and later in Spain and Portugal following the French model, a speaker of the assembly was elected and his functions were regulated in the framework of the rules of the new parliament.

We must remember that at this time there was great precaution about conferring excessive power on an individual who might limit the assembly or condition its decisions, which is why a model of speakership with limited functions

\footnotetext{
${ }^{11}$ BERGOUGNOUS, Georges. Presiding Officers of National Parliamentary Assemblies. A World Comparative Study, p. 1.

${ }^{12}$ MARONGIU, Antonio. "Parlamento (storia)". In CALASSO, Francesco (ed.). Enciclopedia del Diritto. Milano: Giufre Editore, 1981, vol. XXXI, p. 728

${ }^{13}$ FERRARA, Gianni. Il Presidente di Assemblea parlamentare, p. 3.

${ }^{14}$ DAUDET, Yves. La Présidence des Assemblées parlementaires françaises, pp. 16-17.

${ }^{15}$ SIEYÈS, E.J. Consideraciones sobre los medios de ejecución de los cuales los representantes de Francia podrán disponer en 1789. in PANTOJA MORAN, David. Escritos políticos de Sieyès. Mexico: FCE, 1993, pp. 63-114 and CASTALDO, André. Les méthodes de travail de la constituante. Paris: PUF, 1989, pp. 179-183.
} 
emerged. On the other hand, in the initial period mention was made of the speaker, the secretaries and in some cases the deputy speakers, but always as unipersonal bodies and not as a committee with concrete functions. The functions were assigned to officers individually and not yet to the bureau as a collective body.

In the new liberal model of parliament we find that the constitutions did not pay much attention to the speakers of the assembly. In France nothing was said about his functions, while in Spain ${ }^{16}$ and Portugal ${ }^{17}$ the sole focus was on regulating the assembly's relations with the other state powers.

The explanation for this lack of references lay in respect for the parliament's self-regulatory capacity as expressed in its rules. It was also coherent with the reduced relevance of this post in the new liberal political systems. At this time the parliamentary speakership was considered to be a post of little relevance and short duration, with certain barely defined functions, which were not relevant enough to be included in the constitutional text.

Given that the constitutions did not provide precise definitions of these functions, it was the parliamentary rules that did so. In the first rules the functions appeared in less detailed fashion. But as a certain experience of parliamentary work was acquired, the rules became more extensive ${ }^{18}$ and paid greater attention to the legislative procedure and the life of the chamber. This change resulted from the process of rationalization of the parliament that was taking place throughout Europe.

In this first period we can place the functions of the parliamentary speaker under four broad headings: direction of parliamentary work, disciplinary functions, direction of the parliamentary administration and representation of the chamber before other state powers.

In connection with organizing parliamentary work, the rules established that the speaker should open and close sessions, convene sessions and decide on the affairs to be dealt with, direct debates by granting the floor to the deputies requesting to speak and announce the results of voting. These functions were set out in the same way in the chapter defining the functions of the speakership in the three parliamentary rules analyzed $^{19}$.

A second heading concerning the powers of the speaker consisted of disciplinary functions in the chamber ${ }^{20}$. The speaker had to ensure that the rules were observed, he was responsible for keeping order, and he called deputies to order or to keep to the issue under discussion. In Spain and Portugal he could decide to expel an MP if his warnings went unheeded, and he was in command of the public order force guarding the parliament. The French case did not include these functions that strengthened the speaker's powers. In France, he could call a deputy to order, but expul-

\footnotetext{
${ }^{16}$ In Spain the Constitution stated that the speaker of the Cortes should answer the speech of the Crown at the opening of the Cortes (CE1812, Art. 123) and that he should sign the bills approved by the Cortes together with the secretaries (CE1812, Art. 141).

${ }^{17}$ In Portugal the Constitution established that the speaker of the assembly should appoint a commission of twelve deputies to inform the King that the assembly had been constituted (Art. 79, CP1822), that he should sign the bills approved by the Cortes together with the secretaries (Art. 109) and that he should preside over the acts of oath-taking by the new King (CP1822, Art. 126), the Crown Prince (CP1822, Art. 135) and the Regent (CP1822, Art. 151).

${ }^{18}$ For example, in France RPF1789 had 65 Articles and RPF1947 had 116. In Spain RPE1810 had 107 Articles and RPE1982 had 207. In Portugal RPP1821 had 154 Articles and RPP1976 had 253. In Italy RPI1848 had 89 Articles and RPI1949 had 146.

${ }^{19}$ In the first chapter of RPF1789, in the second chapter of RPE1810 and in the first title of RPP1820.

${ }^{20}$ These functions were set out in the chapter dealing with the speakership and in the chapter regulating the sessions in each of the rules of the four countries analyzed.
} 
sion was a decision taken by the assembly according to the rules of 1791 (Chapter III). The speaker in France enjoyed less disciplinary power due to the prevention of an individual's acquiring power over the elected members, which might recall the absolute power of the Monarch and limit the freedom of the members of the assembly.

The development of these parliamentary tasks showed there was a need to create a parliamentary administration to assist the speaker ${ }^{21}$, which was directed by a committee in Spain (Chapter XVIII, RPE1813)22 and in Portugal (Title XI, RPP1820). In France there is no definition of the organization of the parliamentary administration in these early years, although it seems logical to suppose that supervising the employees of the parliament was the responsibility of the people who directed it.

Finally, the parliament's external representation was also channeled through the speaker. In the first place, the speaker represented the parliament before the other bodies of the state and before the citizens. In the second place, he had the task of ensuring that the chambers' agreements were fulfilled, and together with the secretaries he signed the acts and decrees that were approved, and the draft of the minutes of the sessions. Although in the Portuguese case this function was not mentioned specifically.
In the three countries analyzed these functions were assigned to the speaker of the chamber, as the individual body directing it. There were also functions assigned to the secretaries of the parliament. The deputy speakers, where they existed, had the sole function of standing in for the speaker in his absence. But no functions were assigned to the bureau of the chamber as a collective body for its direction. The bureau was not even mentioned as a collective body in either Spain $^{23}$ or Portugal ${ }^{24}$, while in France it was mentioned in the third parliamentary rule $e^{25}$. Therefore, the concept of the parliamentary bureau that we know today did not exist in this first period. The chamber elected the speaker and secretaries to perform the functions of directing the work of the parliament, with certain limited competencies.

Over the course of the $X I X$ and $X X$ centuries the functions of the parliament and the speakership came to be defined with greater precision and important changes were introduced.

The first question we must underscore is the system for electing the speaker of the assemblies. At this initial time the new liberal parliaments established that the speakers should be elected from amongst the deputies themselves. There was no intervention by the Crown ${ }^{26}$ as explained above. This capacity for electing the speaker was placed in question with the Restoration, following

${ }^{21}$ GÓMEZ RIVAS, José Vicente. La Administración parlamentaria española. Creación y consolidación. Madrid: Congreso de los Diputados, 2002.

${ }^{22}$ RPE1810 does not say anything on this question.

${ }^{23}$ RPE1810 and RPE1813 refer to the election of the speaker, the deputy speakers and secretaries, but do not mention the bureau as the collective body for directing the parliament.

${ }^{24}$ RPP1820 refers to the election of the speaker, the deputy speakers and secretaries, but does not mention the bureau as the collective body for directing the parliament.

${ }^{25}$ RPF1789 refers to the election of the speaker, the deputy speakers and secretaries, but does not mention the bureau as the collective body for directing the parliament and RPF1791 refers to the election of the speaker, the deputy speakers and secretaries, but does not mention the bureau as the collective body for directing the parliament. RPF1792 refers to the bureau formed by the speaker and the secretaries, but only establishes functions for each of the individual bodies but not for the collective body. ${ }^{26}$ In France this is stated in Art. 3, 5th Section of Chapter I of CF1791, although this was already the case in the Constituent National Assembly. The same happened in Spain and Portugal. Their Constituent Cortes elected their speakers and the constitutions establish this in Art. 118 of CE1812 and Art. 78 of CP1822. 
the Napoleonic period. It was now the King who would appoint the speaker from amongst five deputies nominated by the chamber itself in France (CF1814, Art. 43), Portugal (CP1826, Art. 21) and Spain (CE1834, Art. 21). But after the 1830 Revolution in France the assembly would once again have the capacity to elect its speaker in all these countries ${ }^{27}$, except in the periods of the dictatorships in Spain (1939-1975) and Portugal (19331974). This dispute over which authority should appoint the speaker, the King or the parliament, concluded with the primacy of the parliament's autonomy over the royal power up until the present day $^{28}$, thus marking a point of rupture with the tradition of the representative assemblies of the Ancien Régime.

The second aspect to underscore is the duration of the mandate. In these first parliaments the period for acting as speaker was limited to fifteen days in France ${ }^{29}$ and one month in Spain and Portugal $^{30}$ and he could not repeat tenure until a period of time had passed ${ }^{31}$. This rule was aimed at limiting the emergence of political figures with considerable power who might condition the debates of the chamber. But this situation was to disappear from 1814 onwards in France, from 1827 in Portugal and from 1834 in Spain. The elected or appointed speakers were now to hold the post for the whole period of parliamentary sessions ${ }^{32}$ as opposed to the speakership's being limited to one month in the previous model. Nor was there a limitation on repeated tenure of the post, as had occurred in the rules in the period of the liberal revolution in France, Spain and Portugal. This change marked an evolutionary step towards a stronger speakership, with greater political relevance and a longer duration ${ }^{33}$. That is to say there was an evolution towards a model of speakership in which it was possible for political figures of some stature to emerge, who were to play a more relevant role in the future ${ }^{34}$.

The functions of the parliamentary speakerships also evolved over the course of the XIX and $X X$ centuries in the countries we are analyzing.

${ }^{27}$ CF1830, Art. 37, CP1838, Art. 43, CE1845, Art. 29, CI1848, Art. 43.

${ }^{28}$ MANCISIDOR, Eduardo. “Funciones y potestades de la presidencia parlamentaria”, p. 159. ${ }^{29}$ IBI 
The speakership's functions in directing parliamentary work were altered as a result of the intervention of the plenary over the course of the XIX century and the intervention of the bureau and the body representing the parliamentary groups in the XX century. In comparison with the previous period we can observe that the elaboration of the order of business was now conditioned by the approval of the chamber ${ }^{35}$. This limitation of the power of the speakership in relation to the order of business was a further element in shaping a model of speakership with powers limited by the chamber. Without any doubt this situation was due to a model of partisan speakership that was not based on the consensus of the different political forces present in the parliament. Hence the power to establish the order of business, that is, to decide which affairs should be addressed, had to be approved by the plenary and not solely by the speaker who continued to be linked to his

${ }^{15}$ IBIDEM, ff 120 r.- $125 \mathrm{~V}$.

16 IBIDEM, ff. 128 v.- 134 v. The letter from D. Miguel de Múzquíz also contained a request for the prompt delivery of the donation. This was dated 20th September.

On 22nd the Viceroy's letter was received. It simply added to the resolution that he had passed on the Patent of laws to the Prothonotary for it to be duly delivered.

On the same day, the Council answered, also in plain terms "y enterado de la Real determinación, queda esperando ponga el Protonotario la Patente en mis manos para hacer, en consecuencia, lo que me incumbe."

On the same day the Council wrote a letter to D. Miguel de Múzquiz and to D. Javier de Azpiroz in the following tone: "Illmo. Sr. Muy Sr. mío Este rasgo de beneficencia, propio de la incomparable piedad y justificación de S. M., es conforme a la confianza que me inspiraba su Real benignidad, y conducido de su impulso, y no menos de los generosos estímulos de mi fidelidad e innata propensión a cuanto redunda en su Real servicio; desde el punto en que llegó a mis manos el pliego de V. E., he dedicado toda mi atención al acopio de las cantidades del donativo que en las últimas Cortes ofrecieron al Rey los Tres Estados, y, sin embargo, de que hasta ahora no se me ha pasado la Patente, y de que me sería incomparablemente más fácil el apronto satisfaciendo el importe en villetes, considerando será más grato al obsequio a S. M. si se le entregase en real, verdadera moneda, he podido conseguir, a expensas del desvelo que tan justament me merece tal cuidado, proporcionar las cosas de manera que me lisongeo con la satisfacción de que han de lograrse cumplidamente las soberanas intenciones. $Y$ asegurando que después del Rey (Dios le guarde), es V. E., el único a quien debo haya sido atendida mi justicia, le rindo las más expresivas gracias por esta señalada merced, que vinculará eterno mi reconcimieto, y el de todo el Reyno a tan justa, generosa demostración." 24th September the Prothonotary delivered the duly signed Patent. The Council wrote to the Viceroy on the same day that in order to save time and without setting a precedent, it had resolved to publish the Patent in the cabezas de Merindad and in Pamplona, instead of printing it, subject to his superior criteria. The Viceroy showed his satisfaction, praising, the "celo y amor de la Diputación de tan antiguo acreditados".

On an anecdotal level, it seems appropriate to present the outcome of this matter, since from an informative point of view it is invaluable. On 27th September, the Council wrote to the Agent so he would thank those who intervened in the matter, especiaIly D. Pedro Custodio de Echevarría and D. Manuel de Alzpún.

On 4th October the donation, which reached the sum of three hundred thousand pesos, was finally delivered before D. Antonio de Riezu, Royal Scribe, who acted as witness. The Royal Treasurer, D. Josef Martín de Virto, issued a certificate of payment, a legalized copy of which was sent to the Secretary of State.

Likewise, on 9th October the Council agreed to write to Señores Abarca, Cristobál, Salabem and Mendinueta, who had intervened in the matter and had congratulated the Council. The letter was written as follows: " M. I. Sr. Muy Sr mío. Me es de singular estimación la enhorabuenna con que me felicita V. S. por el éxito que ha logrado la tercera instancia, con que he reclamado la piedad del Rey a fin de que en la impression y publicación de la Patente de Leyes de las últimas Cortes se guardasen religiosamente sus Leyes, Fueros y constante práctica, y habiendo contribuido los esmeros de V. S. a suceso tan favorable, y lo mucho que se interesa como tan buen patriota en las felicidades de Navarra, le retribuyo el parabién y repetidas gracias por la fineza con que ha sabido distinguirse V. S. en facilitar una resulta tan deseada, y de importancia muy transcendental en las apreciables libcrtades de este Reyno, y para manifestarle mi gratitud, tendré especial gusto en que $\mathrm{V}$. S. me proporcione ocasiones mayor satisfacción." (IBÍDEM 132 v. ${ }^{\circ}-135$ v. ${ }^{\circ}$ ).

Finally, in $\mathrm{f} 141 \mathrm{v}$ there is a letter from the Agent in Madrid dated 19th November, written as follows. "dado que han trabajado en este asunto para los negocios del Reyno personas a las que no es decente regalar otra cosa que frutos del país, se resolvió enviar seis cargas de vino rancio, tres en barriles y tres en pellejos". 
party of origin.

The disciplinary functions that the speaker fulfilled in a unipersonal way were practically limited to calling deputies to order in the plenary session of the chamber and even expelling them. But for more severe sanctions, such as expelling a deputy for several sessions, he had to receive approval from the plenary of the chamber ${ }^{36}$. The speaker also preserved his authority over the forces of order guarding the parliament. In this area, as in that cited in the previous paragraph, the power of the speakership was limited by the plenary of the chamber, due to the lack of trust in the impartiality of a partisan speakership.

The functions of administering the chamber, in those countries where the speaker exercised them, came to be performed collectively by the bureau or the specific committees from a very early date ${ }^{37}$. Therefore, the administration of the chamber was usually a shared function of the speakership, which meant a further limitation placed on the speakership's use of the material resources and personnel of the assembly.

Finally, the speaker's functions as the representative of the chamber were maintained without alteration. His activity as the spokesperson of the chamber and its representative before other state powers and the citizenry has been maintained up to the present day. We can say that this is one of the essential elements of the parliamentary speakership.

\section{THE TRANSITION TO COLLECTIVE DIREC-} TION

But this evolution of the speakership's functions during the XIX century, which brought a limitation of his powers, was further accentuated in the XX century. The emergence of mass parties and the extension of the right to vote, firstly to all adult males and later to women, brought about an important transformation of the parliaments. Starting in the final years of the XIX century and the early years of the $X X$, deputies from parties that represented the workers and the middle classes began to be present in the parliaments. The chamber ceased to be a space reserved for the elites and became a representation with greater social plurality.

This change in the parliaments was also reflected in the recognition of the parliamentary groups. In practice the deputies were previously grouped according to their political affinities, but they had no formal recognition in the rules. From the start of the $X X$ century, their recognition changed from individual political representation to collective representation, in which the electors no longer identified with the candidates individually but with the parties that proposed them ${ }^{38}$. That is to say, the deputy as a representative of a district directly linked to his electors became a deputy linked to a party and its program, although he did not completely forget about his electors. The deputies assumed a partisan role more clearly ${ }^{39}$, while they continued to play a scrutiny role ${ }^{40}$ and a constituency role ${ }^{41}$. The parties of the elites made room for mass parties and the parliamentary groups became an instrument for articulating the representation of the political parties, organizing parliamentary work and controlling the vote of the deputies. The groups brought together deputies of the same ideology and served to articulate the representation of the parliamentary committees and the deputies' participation in the legislative process and controlling the government. Finally and this has a direct bearing on our study - they also participated in the formation of the collective bodies for directing the parliament. On the one hand, the bureau of the parliament was formed with a proportional representation of the parliamentary groups, and on the other, a new body was formed, the conference of the presidents of 
the groups, which was to participate in directing parliamentary work.

Recognition of the parliamentary groups in the countries we are analyzing occurred from the start of the XX century, although the lives of the parliaments were to be cut short by dictatorships in Portugal and Spain and the II World War in France and Italy (in this latter case by fascism as well). This meant that the effect of the formation of parliamentary groups in the bodies directing the parliaments would only become clearer after the II World War.

As noted above, recognition of the parliamentary groups occurred in the early decades of the $X X$ century. In France the reform of the rules in 1915 recognized the parliamentary groups in the Chamber of Deputies (RPF1915, Art. 12), although the parliament's life was to be cut short by the II World War. In Italy the rules of 1900, reformed in 1920, created the parliamentary groups, although they disappeared with fascism's rise to power and the reform of the chamber's rules in $1925^{42}$. In this case the parliament did not disappear as it did in France. Instead it underwent a process of "deconstruction" that progressively altered the chamber through changes in the electoral legislation and the procedures of parliamentary life ${ }^{43}$, resulting in the suppression of the lower chamber and its replacement by the Camera dei fasci e delle corporazioni4 ${ }^{44}$ made up of appointees. This chamber abandoned "any simulacrum of politico-electoral representation" 45 and there was no room for debate or any form of opposition to fascism. In Spain recognition of the parliamentary groups came later. This occurred in 1931 with the II Republic (RPE1931, Art. 11), following a period in which there was no parliament during the dictatorship of General Primo de Rivera (1923-1930). In this case, the parliament also disappeared with the dictatorship of General Franco (1939-1975). In Portugal the parliamentary groups were not re- cognized in this period because the dictatorship (1933-1974) transformed the parliament into a corporative assembly in which there was no place for parties. It was to be the Constituent Assembly of 1975 that recognized the parliamentary groups (RPP1975, Title III, Chapter III) after the end of the dictatorship.

The parliamentary groups were thus recognized starting in the first decades of the century, but in practice this had no significant effect in modifying the bodies directing the chambers in these countries, due to the ending of the activities of the parliaments or their transformation into corporative assemblies.

The return to democracy after the II World War in France and Italy, and the end of the dictatorships in Portugal (1974) and Spain (1975), was to permit the recovery of democratic parliaments. In this new democratic framework the parliamentary groups were recognized in the constitutions of France (CF1946, Art. 11), Italy (CI1947, Art. 77 and 82), Portugal (CP1976, Art. 162, 179, 183 and 197) and Spain (CE1978, Art. 78) and acquired increasing relevance in the life of these parliaments.

As noted previously, the bodies directing the chamber were also modified by the effect of the recognition of the parliamentary groups, especiaIly following the II World War with the widening of the functions of the parliamentary bureau and the creation of the conference of presidents. With this change directing parliamentary work became the shared responsibility of the three bodies: the speakership, the bureau and the conference of presidents .

The speakership shared part of its functions with the body for the collective direction of the chamber, the bureau, of which the speaker was a member. In reality we are speaking of two different bodies, on one side the speakership and, on the other, the bureau with its differentiated functions and a differentiated election procedure. The 
specific procedure for electing the speaker and the particular functions assigned to him, which were different from those performed by the bureau, confirm this idea that there were two differentiated bodies for directing the parliament. On the one hand, the unipersonal body, the speaker. On the other, the collective body, the bureau, of which the president formed part .

\section{The parliamentary bureau}

Although the parliamentary bureau appeared in the parliamentary rules from the XIX century onwards, it did not initially have any functions assigned to it as a body for the collective direction of the chamber; or if it did, they were of little relevance. In France the first mention of the parliamentary bureau appeared in the rules of 1792 (RPF1792, Chapter I), although it was assigned no functions as a body of collective direction. In subsequent rules all mention of the bureau disappeared and only individual bodies were mentioned; or else it appeared in the same way as in 1792 without any attributes of its own as a body for the collective direction of the chamber. In the reform of the rules of 1915, carried out in 1932, the bureau appeared with the function of confirming the quorum and issuing licenses to the deputies.

In Portugal the first mention of the bureau of the chamber appeared in the rules of 1827 (RPP1827, Art. 13), although it had no functions as a collective body of direction. The functions were assigned to the speaker and the secretaries, as individual organs of direction, who were the ones that made up the bureau. From 1837 onwards the bureau as a collective body acquired functions concerning the administrative direction of the parliament (RPP1837, Art. 119). In 1876 it acquired functions in the management of the secret sessions and continued to have functions in the administration of the chamber, although it did not yet acquire the political character it was to have from 1975 onwards.

In Spain the first mention of the bureau appeared in the rules of 1847 (RPE1847, Art. 5) although it was not assigned functions as a collective body. Subsequent rules were to continue this model (RPE1854, RPE1867, RPE1873). It was under the II Republic (1931-1939) that the bureau acquired functions in the direction of the personnel of the chamber and parliamentary work. In the rules of 1934 its functions were maintained and widened to include competencies concerning the status of the deputies, processing bills and procedures to dismiss members of other state institutions.

In Italy mention was made of the bureau, formed by the speaker, deputy speakers, secretaries and questors, in the rules of 1848. In this case it was assigned the function of reviewing the minutes (RPI1848, Art. 71). Starting with the rules of 1863 it acquired the function of managing the personnel of the chamber (RPI1863, Art. 85) and from 1868 onwards it took on the function of approving the rules of the administrative services of the chamber (RPI1868, Art. 11). In 1888 its functions were widened to include noting abstentions when votes were taken (RPI1888, Art. 99). Starting in 1920 it was the bureau that authorized the formation of parliamentary groups. After the fascist period the new parliamentary rules were based on those of 1900 (RCI1946, RPI1946 and RPI1949), which is why the bureau did not acquire any more functions of relevance until 1971, when the rules underwent an in-depth renovation.

In the four countries analyzed we can observe how the bureau existed as a collective body for directing the chamber but with very limited functions. It was the transformation of the parliament resulting from the creation of the parliamentary groups that brought the bureau's conversion into a real body of collective direction of parliament. 
But this change was only to become a reality, with the widening of its competencies, following the reconstruction of the democratic parliaments after the II World War or the end of the dictatorships, with the exception of the Spanish case, where the rules of 1931 and 1934 introduced relevant changes.

The bureau of the chamber in France was mentioned in the Constitution of 1946 (CF1946, Art. 11, 12 and 14) and the rules assigned it wider functions than in the period prior to the war. It became the body that managed the creation of the parliamentary groups (RPF1946, Art. 12), that organized the processing of laws (RPF1946, Art. 20, 70), voting (RPF1946, 74, 83) and the modification of the minutes (RPF1946, Art. 41.5), that approved the licenses of the deputies (RPF1946, Art. 42.4) and some disciplinary sanctions (RPF1946, Art. 107 bis), and approved the rules for the chambers' services (RPF1946, Art. 112).

In Italy it was the rules of 1971 that made the bureau into a body similar to the French case. In addition to managing the administration of the chamber, as it already had done in earlier rules, it now managed the parliamentary groups and committees (RPI1971, Art. 12).

In Portugal the Constituent Assembly created after the dictatorship recognized the parliamentary groups (RPP1975, Title III, Chapter III) and considered the bureau to be a body with competencies in maintaining the assembly's security and freedom, managing the deputies' right to speak and their requests for information, announcing the deputies' loss of their mandate, regulating public access, managing the administration and economy of the chamber (RPP1975, Art. 18) and interpreting the rules (RPP1975, Art. 86). The rules of 1976 added to these functions that of assisting the speaker in his functions and resolving claims regarding the minutes (RPP1976, Art. 34).

Finally, in Spain the Constituent Cortes elected in 1977 converted the bureau into the collective representative of the congress and its governing body (RPE1977, Art. 22) and gave it broad competencies in organizing the work of the chamber . The members of the bureau formed part of the interior government committee (RPE1977, Art. 38) and the rules committee (RPE1977, Art. 40). That is to say it was now the body responsible for the administrative management of the chamber and for directing parliamentary business. This change was consolidated in the rules of 1982 that strengthened the powers of the bureau in relation to the other state powers, it was the body that established general resolutions for interpreting the rules (RPE1982, Art. 32), that decided on all the procedures involved in processing laws, motions of censorship or confidence, etc. , and that received the residual competencies for directing the chamber .

In short, after the II World War and the end of the dictatorships the bureau became the body that managed the parliamentary administration and processed legislation.

\section{The conference of presidents}

Together with the bureau we must also analyze the conference of presidents, the body on which all the parliamentary groups are represented (Junta de Portavoces [Board of Spokespersons] in Spain, Conférence des Présidents [Conference of Presidents] in France, Conferência de Líderes [Conference of Leaders] in Portugal and Conferenza dei Presidenti di Gruppo [Conference of Group Presidents]). This collective body is also presided over by the speaker of the chamber.

The origin of this body was later than that of the bureau. As noted above, the bureau appeared early on in the parliamentary rules, although its acquisition of functions as a collective body was to come later. In the case of the conference of 
presidents, this can be found in France following the II World War. The rules of 1946 already spoke of the meeting of presidents of the groups that, together with the deputy speakers of the chamber and the presidents of the committees under the presidency of the speaker of the chamber, established the order of business of the sessions and their possible modifications (RPF1946, Art. 34). In Italy, in 1950 the parliamentary rules of 1949 were reformed and a conference of presidents was created with competencies similar to those in the French case. But it was to be the rules of 1971 that gave the parliamentary groups a central role in the life of the Italian chamber, through their competencies for organizing parliamentary work (RPI1971, Art. 13, 23.2 and 24).

In Portugal the rules of 1976 established that the groups should be heard when the order of business was drawn up, and also in other affairs necessary to the efficient working of the chamber (RPP1976, Art. 20 and 30).

In Spain the parliamentary rules of 1931 and 1934 had recognized the parliamentary groups, but had not created the conference of presidents. In 1977, following the death of Franco, the Constituent Cortes, in the rules of 1977, made the conference of presidents responsible for organizing the work of the chamber (RPE1977, Art. 27), following the model we have been discussing. Concretely, it was to participate in setting the order of business for the sessions (RPE1977, Art. 54.1). These competencies continued in the rules of 1982, but added to them were its participation in the creation of the committees of the chamber (RPE1982, Art. 50), in organizing voting (RPE1982, Art. 73.2) and in deciding whether a bill should be processed with a single reading (RPE1982, Art. 150).

3. The reasons for this transformation
From the above we can state that after the II World War the direction of parliamentary work underwent a radical transformation with respect to the model of speakership that had been consolidated over the course of the XIX century. The emergence of mass parties in the late XIX century and their entrance into parliament gave rise to the change we are referring to. The parliamentary groups into which the deputies of these parties were organized from the early XX century onwards became one of the fundamental elements for the organization of parliamentary life. These groups participated in directing the work of parliament through the presidency of the bureau and the conference of presidents, something that become particularly evident after the recovery of democracy in the countries cited.

The II World War produced important changes in western societies in different spheres. In contrast to the relevance of individual leaders prior to the conflict, greater value was now placed on the collective rather than the individual after the war. The hyper-leadership of the different fascisms and communism was countered with a greater assertion of collective leaderships. Facing presidentialist models, the IV French Republic, for example, placed greater importance on parliament in the political system. It is in this context that we should understand the reduction in the weight of the parliamentary speakership facing the collective bodies, the bureau and the conference of presidents. There was an increase in the presence of instruments that limited individual powers, following the traumatic experience of the dictatorships.

On the other hand, in the countries we are analyzing the parliamentary speaker was a party man. In contrast to the British model, the individuals elected to preside over the parliaments in the countries analyzed did not abandon their party loyalty and their continuity in the post was 
dependent on the game of majorities and minorities. Of the thirteen elections for the speakership of the French Assembly in the IV Republic, on five occasions the speaker was elected with less than $60 \%$ of the votes cast, on six with less than $70 \%$, and only exceeded this percentage on two occasions. In Italy between 1945 and 1958 there were six elections, in only one of which was the speaker of the chamber elected with more than $70 \%$ of the votes cast. That is to say we are dealing with a partisan speaker, elected by the majority, but who did not enjoy the support of the minority and who could only revalidate his mandate if the majority was maintained.

This model of speakership in which the speaker continued to belong to a political party was manifested in parliament in all its clarity in two aspects. In the first place, the speaker was proposed by his party, and normally by the party leadership; he was not proposed by the parliament or by his parliamentary group, as in the British case in recent decades and especially since 2009 .

In the second place, the speakers in the chambers of France, Italy, Portugal and Spain formed part of the parliamentary group made up of the deputies of the party for which they were elected. On being elected speakers of the chamber they did not leave their group. A third manifestation of the continuity of this relationship with the party was his participation in the voting. In the countries cited the speakers voted in the same way as their group and not with a vote to uphold the status quo as in the British case. Theirs was a partisan vote in the fullest sense of the term.

This model of partisan speakership was another of the reasons why the bureau and the conference of presidents became bodies that limited its power in controlling the legislative process. The impartiality of the speakers had to be guaranteed by the participation of the majority and the minority in the collective bodies that directed the chamber.

In the two bodies we are referring to representation was proportional to the weight of each parliamentary group in the chamber. In the case of the conference of presidents this was because all the groups were represented in it and, in case of disagreement, its vote was to be weighted according to the number of deputies in each group . In the case of the bureau this was because it always contained a plural representation as it was formed with a limited vote, that is to say each parliamentarian when electing the deputy speakers or secretaries could not vote for all the posts to be filled, which guaranteed the presence of different groups. Or because a list was drawn up with candidates from different groups taking into account the number of deputies of each of the latter because this was ordered by the rules or because the parties reached an agreement. In this way plurality in the composition of the collective ruling body of the chamber and respect for different opinions in its decision-making were guaranteed.

In the model of speakership that was consolidated after the restoration of the democratic parliaments, the functions of administering parliament, approving some sanctions against deputies, interpreting the rules and part of directing parliamentary work (taking decisions on the processing of laws, amendments, etc.) corresponded to the bureau. In its turn, the conference of presidents drew up the order of business and approved modifications made to it. That is to say it participated in one of the main elements of the legislative process. Nonetheless, the influence of the government in defining the legislative agenda was now essential, given that the majority of the laws passed have their origin in bills proposed by the government itself .

The speaker, for his part, continued to keep the competencies that had necessarily to be exercised by a unipersonal body and that could hardly 
be shared with a collective body. These included his competencies in the plenary as a debating technician, some functions related to keeping order in the chamber, the institutional functions of a constitutional nature that he exercised individuaIly, and those of representing the chamber. To these individual competencies were added those he shared with the bureau and the conference of presidents, given that he was the president of both bodies, and therefore played a prominent role in their decision-making.

\section{CONCLUSIONS}

The model of parliamentary speakership in France, Italy, Portugal and Spain is the result of a long evolution over the course of the $X I X$ and $X X$ centuries.

In the process of the liberal revolutions the design of the new parliaments generated a model of speakership conceived as the individual body for directing the chamber, aided by the work of the secretaries.

The functions of the president were centred on four big questions: the direction of parliamentary work, disciplinary functions, the administration of the chamber and the latter's institutional representation.

Over the course of the XIX century the parliamentary speakership was transformed into a relevant post in the political systems of these countries with the lengthening of the mandate and the possibility of repeated tenure. On the other hand, the parliamentary rules established with greater precision and detail the functions of the speakership, while in questions like discipline and the approval of some issues relating to legislative procedure the speaker had to receive the approval of the plenary of the chamber, thus limiting his power.

But the fundamental change occurred with the creation of the parliamentary groups and the changes to the parliaments that take place after the II World War. These modifications also significantly affected the bodies that direct the chamber and the functions they perform.

With these changes the speakership kept its functions related to directing the debates of the plenary and the representation of the chamber. As president of the bureau he participated in its functions of administering parliament, approving some sanctions against deputies and part of the direction of parliamentary work. As president of the conference of presidents he took part in its functions of planning the work of parliament.

In sum, there was a passage from a model of individual speakership to another that we can define as a shared model, adapted to a vision of the political institutions with balances that place a limit on individual authority and guarantee greater participation in political activity by the minorities. 
PARLIAMENTARY SPEAKERSHIP: FROM INDIVIDUAL SPEAKERSHIPTO THE COLLECTIVE DIRECTION OF PARLIAMENTARY WORK

Dr. Mikel Urquijo Goitia 
PARLIAMENTARY SPEAKERSHIP: FROM INDIVIDUAL SPEAKERSHIPTO THE COLLECTIVE DIRECTION OF PARLIAMENTARY WORK

Dr. Mikel Urquijo Goitia 
PARLIAMENTARY SPEAKERSHIP: FROM INDIVIDUAL SPEAKERSHIPTO THE COLLECTIVE DIRECTION OF PARLIAMENTARY WORK

Dr. Mikel Urquijo Goitia 
PARLIAMENTARY SPEAKERSHIP: FROM INDIVIDUAL SPEAKERSHIPTO THE COLLECTIVE DIRECTION OF PARLIAMENTARY WORK

Dr. Mikel Urquijo Goitia 
PARLIAMENTARY SPEAKERSHIP: FROM INDIVIDUAL SPEAKERSHIPTO THE COLLECTIVE DIRECTION OF PARLIAMENTARY WORK

Dr. Mikel Urquijo Goitia 
PARLIAMENTARY SPEAKERSHIP: FROM INDIVIDUAL SPEAKERSHIPTO THE COLLECTIVE DIRECTION OF PARLIAMENTARY WORK

Dr. Mikel Urquijo Goitia 
PARLIAMENTARY SPEAKERSHIP: FROM INDIVIDUAL SPEAKERSHIPTO THE COLLECTIVE DIRECTION OF PARLIAMENTARY WORK

Dr. Mikel Urquijo Goitia 